\title{
Principles of Financial Regulation: A Dynamic Portfolio Approach
}

Joseph E. Stiglitz

Economists seeking explanations for the global financial crisis of 1997-99 are reaching consensus that a major factor was weak financial institutions, which resulted in part from inadequate government regulations. At the same time many developing countries are struggling with an overregulated financial system - one that stifles innovation and the flow of credit to new entrepreneurs and that can stunt the growth of well-established firms. In particular, too many countries are relying excessively on capital adequacy standards, which are inefficient and sometimes counterproductive. The author argues that financial systems can be reformed successfully using a "dynamic portfolio approach" aimed at managing the incentives and constraints that affect not only financial institutions' exposure to risk but also their ability to cope with it. The article sets out general principles of financial regulation and shows how the dynamic portfolio approach can help countries deal with the special problems that arise during the transition to a more liberalized economy as well as those that arise in dealing with a financial crisis similar to the 1997 crisis in East Asia.

As dramatic as it was, the global financial crisis of 1997-99 was only the most recent in a rash of crises that have devastated market economies over the last 25 years. By one calculation almost 100 countries experienced a severe currency or financial crisis during that period, ${ }^{1}$ with adverse consequences for their national budgets and economic growth. Such patterns clearly call for an explanation; although there has been no dearth of suggestions, a consensus is growing that at least part of the explanation lies in weak financial institutions, which result in part from inadequate government regulation. The pendulum has come full circle: from the burst of enthusiasm over deregulation, policymakers now appreciate why it is that the most successful economies have long had a strong tradition of financial regulation. In the United States financial regulation dates back to 1863, in the middle of the American Civil War, when it became apparent that a strong banking system was essential to create a new national economy and that such a system required a strong national regulatory structure. The most recent major lapse in regulation, the deregulation effort that 
began in 1981, led to the savings and loan debacle. The consequences of that crisis were so severe that the U.S. economy did not recover for close to a decade.

But many developing countries are struggling with precisely the opposite problem-an overregulated financial system that stifles innovation and the flow of credit to new entrepreneurs, stunting the growth of even well-established firms. One of the many adverse effects of the East Asian financial crisis is that countries have become wary of reforms that affect the financial sector, aware that they may leave the country worse off. This article argues that reforms are possible — and indeed needed — and can be undertaken without undue fear, but success requires understanding the basic principles of financial sector regulation. The article sets forth those principles.

Even before the crisis, a theoretical literature argued that the nature of financial market failures necessitated a strong role for government (Stiglitz 1993). Failures in the banking system have strong spillovers, or externalities, that reach well beyond the individuals and firms directly involved. To avoid a financial collapse, governments typically bail out the affected entity, whether or not formal deposit insurance is in place; this intervention itself gives rise to problems of moral hazard. ${ }^{2}$ Although the absence of formal deposit insurance might give depositors a slightly increased incentive to monitor financial institutions (because there is some uncertainty about whether they will actually be bailed out), individual monitoring is actually inefficient. Monitoring is a public good, and it needs to be publicly provided. Of course, at a more practical level, a small depositor cannot be expected to examine the books of a bank on a weekly basis; there is strong evidence that regulators and rating agencies have difficulties doing so. Indeed, the widespread misconceptions about the appropriate strategy for regulating the financial sector suggests that even so-called experts are not fully aware of some of the key issues. Why, then, should one expect more from an individual depositor with little training, interest, or capacity in the arcane details of financial accounting?

Despite its long history, financial market regulation is poorly understood, as evidenced by the disasters associated with deregulation in industrial and developing countries. Often such measures were pushed through in a burst of enthusiasm for free markets without recognizing the inherent market failures associated with such markets - and without remembering the disastrous history of free (unregulated) banking (Caprio and Vittas 1997; Vives 1991). Today few economists advocate unregulated banking, but a similar ideological agenda has pushed excessive reliance on a single regulatory instrument — capital adequacy standards. The belief is that this measure entails the minimal interference with the workings of the market and avoids the well-recognized problems of unregulated banks. A deeper analysis of the financial sector, however, shows that such reliance is not only inefficient but may even be counterproductive under some circumstances.

This article presents a general approach to financial sector regulation that I refer to as the dynamic portfolio approach. It recognizes that asymmetric information gives 
rise to the need for regulation and examines the regulatory structure from the perspective of risk management. The article focuses on managing the incentives and constraints that affect financial institutions' exposure to and their ability to cope with risk. It argues that a number of instruments are available that can be used to complement each other. The way these instruments are mixed differs over time and with the country's level of economic development. Underlying the analysis is the recognition not only that financial institutions play a central role in the economy but also that financial institutions are both a source of risk to and are affected by risks from the rest of the economy. Thus, the design of the regulatory structure needs to be sensitive to the ability of, say, the corporate sector to manage an absorb risk.

This article outlines the general principles of financial regulation and goes on to discuss the special problems that arise in the course of the transition toward a more liberalized economy. Although I recommend a process of gradual transition, it is apparent that managing the transition requires considerable subtlety; in the early stages some regulations may actually have to be tightened. The final section discusses the special problems that arise in dealing with a financial crisis similar to the 1997 crisis in East Asia. The regulatory framework required for dealing with such systemic problems needs to be markedly different from that employed in dealing with an isolated weak bank.

\section{Basic Principles}

Underlying the need for bank regulation is a discrepancy between social and private returns on assets (risk), which can create an incentive for bank owners and managers to engage in excessive risk. Imprudent lending is not the only problem. Akerlof and Romer (1993) emphasize banks' incentives for looting. They note that the mechanisms of control are similar except that the scope for using criminal penalties as incentive devices is greater. In practice, of course, determining whether looting has occurred is often difficult, which limits the applicability of such penalties. There are thus two approaches to regulation: first, trying to alter incentives so that social returns and private incentives are better aligned; second, imposing constraints that limit the extent to which owners and managers can deviate from appropriate risk.

\section{Improved Incentives}

Incentives are improved through increased capital, so banks have more to lose if they gamble. Such capital takes two forms: standard capital requirements, which force banks to maintain a certain level of net worth or a tranche of uninsured capital; and franchise value, which is the present discounted value of future profits. If a bank gambles on an investment and loses, a larger capital base means that the bank bears 
more of that loss; if it loses enough, it goes bankrupt and cannot reap future profits-it loses its franchise value.

But the enthusiasts of capital adequacy standards have missed an important subtlety: Increasing capital requirements lowers the franchise value of the bank, so that the net benefit is much less than would seem to be the case and may even lower the overall capital value of the bank, thus actually adversely affecting incentives.

The reason is simple. The kind of equity capital required to meet capital adequacy standards has a high cost (otherwise there would be no need for a government requirement). Thus, by raising the amount of high-cost capital (relative to the low-cost deposits), the residual (franchise) value is reduced. There is an important and obvious corollary: financial market liberalization - that is, increased competition and the elimination of ceilings on deposit rates - lowers franchise value and thus leads to increased risk-taking. This is the underlying reason for the systemic relationship between liberalization and financial sector crises. To be sure, increased competition might have produced long-term benefits if no financial crisis had occurred. But the frequency of such crises suggests that all too often those benefits are not achieved, and indeed, the fact that economic growth is significantly slowed for five years after a crisis strongly suggests that the net benefits are questionable at best. In fact, crosscountry studies question whether there is any systematic relationship between capital market liberalization and either growth or investment (Rodrik 1998).

Advocates of capital adequacy standards have a reply. The problem, they assert, is that capital adequacy standards were simply not set high enough or were not rigorously enforced. I will come back to the latter objection; here I consider the former.

There is, to be sure, a level of capital adequacy that is high enough to ensure that banks will not engage in gambling behavior. But these levels entail a cost. Because the capital is expensive, banks are only be able to pay depositors relatively low interest rates. (To put it another way, the marginal return to deposits is lowered.) Hellman, Murdock, and Stiglitz (1998) show that relying solely on capital adequacy standards is inefficient. By accompanying capital adequacy standards with ceilings on deposit rates, it is possible to offer depositors precisely the same interest rate they would have achieved under the gambling-preventing capital requirements, yet banks would be unambiguously better off. Indeed, one can go further: the deposit rate can be raised with a slight accompanying increase in the capital requirement from that level, thus mobilizing more savings and attaining the same level of safety and soundness of the banking system that would have been achieved by relying solely on capital requirements. ${ }^{3}$

Regulators need to recognize that capital adequacy standards by themselves may actually induce banks to engage in riskier behavior: As they seek returns to offset their higher costs, they engage in increased risk-taking, partly offsetting the benefits conferred by the capital adequacy standards. That is why capital adequacy standards have to be set so high that banks are forced to lower deposit rates. 
To offset this problem, regulators have attempted to make capital adequacy standards reflect the risks that banks undertake. But the risk adjustments that are put into place are so inadequate - almost intrinsically so - that they do little to resolve the problem and may actually exacerbate it by providing distorted incentives. First, they approach risk on the basis of an assessment of each asset, yet the risk faced by the bank is a result of the correlations among all the risks. A bank portfolio consisting of a large number of highly correlated but relatively low-risk assets may in fact be far riskier than a bank portfolio consisting of higher risk assets that are negatively correlated or not correlated at all. This, of course, is the point of risk diversification. In the past problems have occurred when banks failed to evaluate properly the correlation among assets. Because of the effects of contagion, investments in Mexico and Brazil in the 1980s turned out to be highly correlated, with disastrous effects on the banks' balance sheets.

Today, sensitivity to these issues is heightened, although they remain poorly captured within the capital adequacy framework. But a new set of correlations - that which occurs between credit and market risk- has proved even more troublesome. Originally, risk adjustment focused only on credit. Although they have subsequently been amended, the risk adjustments are treated and applied uniformly by all countries. The responses to this neatly illustrate the distorting consequences of inadequate risk adjustments and how they can expose banks to greater risk. To offset the high capital adequacy requirements, banks sought high-return investments that were not risk weighted, and they could easily find such assets in long-term Treasury bills. These bills paid high interest rates, presumably to offset the high risks associated with market value. But the banks were allowed to treat the additional return as income (rather than being forced to put the "risk premium" aside to provide reserves against the possible contingency of a fall in market value). An active debate on the subject took place in the United States. Many economists supported the principle that the regulatory framework should be based on transparent systems in accord with risk principles. The chairman of the Federal Reserve Board, however, took the position that it was necessary to comply only with the Basle principles, which emphasize the importance of independent regulatory authorities, early intervention in the event of financial distress, transparency, and market discipline. ${ }^{4}$ In this particular case, the perhaps unexpectedly large deficit reduction that U.S. president Bill Clinton managed to push through Congress (by a slim margin) in 1993 provided the setting for a marked reduction in long-term interest rates. The result was an increase in long-term bond asset values, which effectively recapitalized the banking system (Stiglitz 1998). Some gambles do pay off. But if the perhaps more likely scenario had played out - a continuation and even an expansion of the soaring deficit-interest rates could have risen, leaving the banks in dire straits.

The recent crisis has shown the danger of paying undue attention to the correlations between credit and market risk. A bank may believe that it has purchased cover 
for an exposed position, but if the probability is high that the provider of that cover will go bankrupt - especially under the circumstances in which it is called on - then the bank does not really have adequate insurance against risk. If those who provide cover have an inadequate capital basis relative to their risk exposure (which depends on the correlation of their risks), then such problems may easily arise, as occurred in the crises in the Republic of Korea and Russia. But note the almost impossible position that this imposes on regulators. Not only do they have to look at the nominal cover, they have to look at the balance sheets of those providing the cover.

Capital adequacy standards (with or without risk adjustments) are only one way to enhance incentives. Other ways entail strategies that increase the institution's franchise value, such as restrictions on deposit and lending rates and on entering the market. Restrictions on deposit rates can be an effective part of a portfolio of financial regulation, one that strictly dominates reliance on capital adequacy standards. (To be sure, one must guard against policies intended to circumvent these restrictions, such as hidden forms of service provided to depositors. Typically, these go only a little way in undermining the effectiveness of these ceilings.)

Advocates of financial market liberalization have often attacked ceilings on lending rates because they restrict banks' incentive to lend to high-risk ventures. But that is exactly the point. Such risky lending is associated with a systematic discrepancy between social and private returns because of the implicit protection provided by deposit insurance. Such ceilings may be an important complement to other regulatory instruments, given the limitations referred to earlier and discussed in greater detail below.

\section{Constraints}

The simplest constraint is designed to prevent banks from engaging in excessively risky lending and to ensure that when such lending occurs, the bank is adequately compensated by a high interest rate, has sufficient capital to absorb any losses, and promptly sets aside reserves when loans become nonperforming. This kind of monitoring forms the basis of traditional bank regulation. But the cost of such regulation is high, and because regulators typically are less informed than lenders, the scope for abuse is wide. Hence, especially where regulatory capacities are weak, it is better to rely on more direct constraints.

Several categories of constraints are imposed on banking systems, including those on processes and on categories of loans, on entry into the market, and on interest rates. For instance, before liberalization, Thailand (and many other countries) restricted the amount banks could lend for speculative real estate ventures and imposed strict collateral requirements on such loans. Many regulatory authorities are considering restrictions on the use of derivatives. A common set of restrictions relates to self-dealing (insider loans). The long, sad experience of such loans makes the dan- 
gers of such transactions clear. Most countries impose restrictions on who can own and run banks. The risk of a violation of fiduciary responsibilities is simply too great to entrust these funds to those with, say, criminal records.

Increasingly, governments are supervising risk-management systems. But the limitations of these systems have become increasingly clear, even in the industrial countries that have tried to implement them. Supervisors have repeatedly failed to detect the risks associated with huge derivative positions. In the absence of sophisticated risk-management techniques, regulators need to rely on cruder approximations of solvency. Thus, they focus on, for example, foreign-exchange exposure (mismatches between assets and liabilities) or (as in the case of Malaysia) the foreign-exchange exposure of borrowing entities.

By the same token, because highly leveraged firms run the risk that they may be unable to repay their loans, regulatory authorities may limit the leverage of firms to whom banks lend. (This is a restraint that few regulatory authorities have actually imposed. Prudent banking might make such a regulation unnecessary if banks had the correct incentive structure. Korea has imposed such constraints.)

Although correlations may not be well measured, the presumption that firms in the same industry are highly correlated (because they are typically affected, at least in part, by similar shocks) naturally leads to restrictions specifying that the entity's asset base be diversified. A long history demonstrates that very rapid and frequent increases in a bank's asset base tend to be associated with high-risk portfolios. This illustrates the value of legally mandated restrictions to prevent such practices. These restrictions may mean that it will take longer for competitive forces to weed out inefficient banks, but well-documented experiences suggest that these risks are outweighed by the attendant benefits. The extent to which limitations on too rapid an expansion of assets can be relied on (like any constraints or incentives) depends on the existence of complementary restraints and incentives. When the incentive structure includes deposit insurance but does not limit interest rates paid to depositors, banks that engage in risky behavior will have an incentive to offer higher interest rates to attract more funds. A form of Gresham's law takes place as risky banks drive out safe banks (Stiglitz 1992).

\section{Systemic Effects}

Subtlety, attention to correlations, and an awareness of systemic effects can guide policymakers in imposing and implementing these regulations. Two examples suffice to make the point. Consider a common constraint: a minimum collateral requirement on real estate loans. Such constraints are useful in two respects. In normal times, the magnitude of an error in judgment is limited. An 80 percent capital requirement may well protect the lender against a misjudgment in the value of the asset or in fluctuations in that value. Even if the borrower cannot repay the loan, the lender is sup- 
posedly fully protected. The fact that the borrower has so much to lose provides an incentive to borrow only if the investment is likely to pay off. Such contracts would thus appear to be incentive compatible.

The problem is that the value of the collateral is highly correlated with the circumstances under which borrowers cannot or do not repay. ${ }^{5}$ The collateral requirements themselves also contribute to the correlation. In an economic downturn (especially an asset bubble crash), many borrowers find themselves unable to repay their loans; some borrowers decide to default on their loans as the value of their collateral falls below the value of the loan. As a result, many assets are put up for sale; the sudden increase in the number of distressed properties for sale leads to a sharp drop in asset prices (intertemporal arbitrage is far from perfect) (Shleifer and Vishny 1997). This decline, in turn, leads to more defaults, and a vicious circle is set in place. The collateral requirements seem to reinforce the downward spiral.

The problems are even more severe when capital adequacy standards are rigidly enforced in the face of an economic downturn and banks cannot raise the funds to recapitalize, as is typically the case. In the resulting credit crunch, banks have to cut back their loan portfolios, forcing many more firms into bankruptcy or, at a minimum, making it impossible for them to service their loans. As each financial institution moves to satisfy capital adequacy standards, the whole system may find its strategy completely undermined, worsening capital adequacy.

\section{Limitations on Regulatory Incentives and Constraints}

Information imperfections give rise to the need for regulation and plague the implementation of regulatory regimes. Three principles are worth noting:

- Capital is imperfectly measured. Ascertaining the true capital-that is, what the bank has at risk - is uncertain. The problem is acute, because most of the assets (loans and holdings of real estate) are illiquid and there are no markets to ascertain their true values. But book value is highly unreliable. Indeed, this is precisely why most economists have supported marking to market value those assets whose values can be easily ascertained. In the United States and elsewhere, the resistance to these reforms, which would increase the transparency of the banking system, has been remarkable. Those resisting have argued that the information may lead to distorted behavior, because only part of the bank's asset portfolio would be marked to market. But the distortions have more to do with how the information is used by regulators and depositors than with the availability of the information itself.

- Constraints are imperfectly monitored. For instance, many mortgage regulations specify that the value of the house must amount to at least two-thirds of the value 
of the property. This restriction is intended to discourage land speculation financed through bank lending and reflects the variability of land values. But valuation typically involves considerable discretion. Insider lending is another practice that is difficult to stop. Although insider lending is prohibited, lending to friends of insiders, who then lend to insiders, is easy to arrange. The savings and loan debacle in the United States demonstrated the large variety of ways by which those who wished to skirt around the regulations could do so-although they also illustrated that one can overstep the bounds and end up in prison.

- These information imperfections are endogenous and thus are affected by the regulatory regime. Regulatory regimes, combined with imperfect information, can lead to highly distorted behavior and actually weaken the banking system. This is a key point: the extent of information imperfections is affected by the consequences of the provision of information. Some examples (following) make this point.

Failure to use "mark to market" accounting is such a case. By relying on book value accounting, management induces perverse incentives in the sale and retention of assets, increasing the discrepancy between market value and book value. Banks sell those assets that have increased in value, recording their gains, but retain those assets that have lost value, thus avoiding the need to record these losses. This technique may stabilize asset values in the economy (as noted in the discussion on collateral), but it means that book value is an upwardly biased measure of true capital. Book value accounting also leads to economic inefficiencies: whether a bank should buy or sell an asset should depend on the relative merits of the bank's ability versus that of other entities to manage and monitor the particular asset.

Worse still, book value accounting offers management an incentive to engage in excessively risky investments, because these provide a greater opportunity to distort "recorded" capital values relative to actual values. Banks have an incentive to reduce the quality of information and to take actions that increase the magnitude of the distortion. ${ }^{6}$

These incentives become more acute the greater the extent to which the capital adequacy standards are binding. One of the consequences of rigidly enforcing capital adequacy standards without appropriate risk adjustments (and, as mentioned, risk adjustments are woefully inadequate) during an economic downturn is that it leads to increased risk-taking and a reduction in the quality of information.

\section{Dealing with Limitations on Information}

There are three complementary approaches to informational limitations. First, select regulatory regimes that are less information intensive. In other words, it may be easier and less costly to monitor certain categories of loans (to make sure that banks are not making, say, real estate loans) than to assess the quality of the loans them- 
selves. Indeed, the reliance on enhancing bank incentives is based on the premise that banks have better information about the loans than do regulators. It is easier to monitor the variables that affect bank incentives, such as capital adequacy. Although that is true, there are limitations-with important consequences-in monitoring capital.

Second, complement the information base on which regulators depend with information provided by markets. Particularly suggestive in this regard is Argentina's strategy, which requires banks to obtain a tranche of uninsured capital. The interest rate that banks pay for such capital provides an indicator of the market's perception of the bank's risk. Typically, the private and public sectors have access to different information. The private sector may, for instance, have better information concerning the condition of the firms to whom the bank has made loans, but regulators may have more up-to-date information concerning the bank's current balance sheet. The information that each has available and the way each processes that information are sufficiently different that both have value. Third, avoid regulatory regimes that undermine the quality of information or at least be aware of their biases and implement offsetting corrections.

\section{Financial Institutions Balance the Benefits and Costs}

If the restrictions imposed on banks become too severe, funds will flow to less regulated nonbank financial institutions. To the extent that banks face significantly greater systemic risks (and more severe moral hazard problems because of the explicit or implicit guarantee of bailouts), this shift may not have overall adverse consequences. But as several recent crises have illustrated, if nonbank financial institutions loom large enough in the economy, they, too, can give rise to systemic risks, and they, too, can become too big to fail. In this process all the arguments explaining why regulation is needed for banks become applicable to nonbanks. The reach of regulation must thus embrace all financial institutions, although the extent and nature of the regulation may differ markedly between banks and nonbanks depending on the role the latter institutions play in the economy.

Developing countries often face greater risks because their economies are smaller and less diversified. At the same time, their risk management capacities are weaker, their risk absorption levels (and built-in stabilizers) are less effective, and their regulatory authorities are more limited. Clearly, regulatory policies need to complement each other. This observation is a reflection of the modern approach to agency theory. This theory, which was developed a quarter of a century ago (Ross 1973; Stiglitz 1974), emphasized the information asymmetries between principles and agents and the often marked differences in incentives that resulted. Incentive systems were designed to align the two. Although the early literature focused on designing reward structures based on (imperfectly) monitored outputs versus (imperfectly) monitored 
inputs, it became increasingly clear that optimal incentive structures used all available information on inputs, outputs, the processes by which decisions were made, and the processes by which inputs were converted into outputs. In a sense, this analysis pushes the evolution of agency theory a step forward by emphasizing the constraints on subsequent opportunities.

I have stressed the importance of interactions between the various parts of the portfolio of regulatory actions. These interactions are often complex and poorly understood. For instance, restrictions on bank lending may adversely affect the institution's franchise value, so that although certain types of risk may be proscribed, overall risk taking might actually increase. More broadly, restrictions on the set of feasible activities necessarily lower expected profits and thus reduce franchise values. Moreover, restrictions may have an adverse impact on incentives, so that even though the ability to engage in excessive risk taking may be reduced, the incentive to do so may be increased. Either tighter oversight or more stringent restrictions on lending may have to be imposed.

\section{Transitions: Financial Regulation in the Process of Liberalization}

This discussion has highlighted some of the problems with financial regulation in equilibrium. But some of the most interesting challenges pertain to the process of liberalization. The recognition that changes cannot occur overnight and that time is needed to build up regulatory capacity suggests that a process of gradual liberalization may be preferable to the rapid liberalizations that have encountered so much trouble. One lesson that has been learned from East Asia's experience is that liberalizing the financial sector before the requisite regulatory structure is in place is a recipe for disaster.

Two further aspects of the transition process have not received sufficient attention. The first concerns announcement effects, meaning that the announcement of even a gradual approach to liberalization has an instantaneous adverse impact on franchise value. The prospect that future profits may decline reduces incentives for prudential behavior well before the liberalization takes effect. Thus, it is important to tighten the regulatory structure initially to prevent entities from indulging in risky ventures. The process of liberalization cannot simply be a successive peeling away of regulations.

Second, the individuals responsible for financial liberalization must be cognizant of the scarcity of trained human resources. The standard challenges have often been noted. Banks and managers are not well prepared for the new competitive environment. Moreover, the previous cushion of profits permitted greater scope for mistakes while still allowing the bank to survive. Indeed, before liberalization, banks often sim- 
ply directed credit according to the government's instructions, with full knowledge that the government would bear the costs of any defaults. Hence they were not really engaged in the central functions of banking - the screening and monitoring of loans (Stiglitz 1998). But although the need for and demands on regulators increase, typically there is a shortage of trained personnel as skilled employees are recruited away by the private sector. The public sector simply cannot compete. This phenomenon was evident in Thailand, whose central bank, well regarded in the 1980s, lost many of its most talented individuals after liberalization.

\section{Regulating in Crises}

Weak regulation, forbearance, and a failure to meet basic capital adequacy standards are common contributors (if not causes) of financial crises. It is thus natural to respond to a crisis by insisting that banks quickly meet capital adequacy standards. But such a policy may actually prove to be counterproductive. The problem arises from the failure to distinguish between systemic problems and isolated bank failures. When a single bank has a problem, shutting down the bank has no systemic consequences and no macroeconomic effects. To be sure, borrowers who relied on that bank may face difficulties until they find alternative sources of funds. Systemic crises, however, are quite different.

Consider a country in which a crisis has occurred and where a large fraction of the financial institutions suddenly do not meet capital adequacy standards. Assume that there is no adjustment in those standards and they are told to quickly comply. The midst of a recession is hardly an appropriate time to raise additional capital, at least from the private sector. Thus, unless the government is willing to provide additional finance, banks have to cut back on lending, curtailing the amount of credit available and forcing some firms into default. In any case, firms' demand for investment capital is likely to be unmet, and they may be forced to reduce their scale of operations. In time, these adjustments can trigger a chain of bankruptcy. Worse still, as firms go bankrupt, the number of nonperforming loans increases, weakening the bank's financial position. Clearly, rigid enforcement of capital adequacy standards may be self-defeating.

Alternatively, the government may finance the restructuring. Too often this is done in a way that ignores the basic rationale for additional capital. The principal reason for strong capital adequacy standards is to provide bank owners with an incentive not to engage in risky behavior and to provide a cushion against shocks so that the government will not be required to bail out the bank. Government-provided funds satisfy neither criterion. Private incentives are unchanged because the amount of private money at risk is unchanged. It is hard to see how government-as-owner should be more prudential than government-as-regulator. The government cushion 
affects only the timing of the provision of public funds. It has no effect on the amount of public funds that will eventually have to be disbursed.

Moreover, such funds can be counterproductive. If the government raises money in the conventional way, these funds may crowd out public expenditures on other items. Although the government maintains demand by sustaining bank lending, the aggregate contraction of expenditures on education or health clearly has contractionary effects on the economy as a whole. Alternatively, the banks may simply be shut down, with even more disastrous effects as credit is cut off and the chain of events described earlier is set in motion.

A more appropriate objective of bank restructuring should be to maintain the flow of credit while ensuring that lending is prudent. The dynamic portfolio approach advocates a tightening of oversight, including possible restrictions on categories of acceptable activities. This approach is accompanied by a longer-term requirement for the satisfaction of capital adequacy standards (to guard against banks issuing dividends).

In a world in which many economists, let alone analysts, do not understand the fundamentals of bank regulation, public relations may require that banks at least appear to satisfy high capital adequacy standards. There are ways that this may be done at low budgetary costs. For example, rather than invest in a firm directly, banks may lend to the government at low or 0 percent interest rates, with the proceeds invested in the equity of a firm. The government's implicit guarantee reduces the capital adequacy requirement for that loan, because the risks associated with the asset and liability differ markedly. Although this transaction nets out on the government's capital account, it improves the bank's ratio of net worth to assets. (At the same time, it makes the inadequacy of capital adequacy standards clear.)

When shocks to the financial system are large enough or lending mistakes are big enough, the net worth of a bank may actually be negative. At this point, the government faces more fundamental problems. If there is an explicit deposit insurance system, the insurance should pay off the insured depositors, putting the bank effectively into bankruptcy. Whether the bank should be shut down or recapitalized depends on a judgment about the bank's competence. More subtle problems involve the informational and organizational capital embedded in the bank, with some attention to moral hazard issues on the one hand and credit constraints on the other. The basic criterion should be: Does this financial institution have organizational and informational capital that make it valuable in screening and monitoring loans? But this basic criterion must be modified in two ways: the government needs to be aware that closing down a bank (or at least punishing managers through severance) provides incentives for financial institutions in the future to be more prudent. This would mean that a marginal bank-one whose net value as an ongoing enterprise might be slightly positive-might be shut down. But offsetting this decision is the fact that when a country faces a macroeconomic slowdown, the systemic effects of closing 
down a bank may be significant. Thus, regulators might decide to keep a marginal bank alive, even though its net value as an ongoing enterprise might be slightly negative.

The way that the savings and loan crisis in the United States was handled emphasizes the importance of maintaining institutional and organizational capital. Few banks were actually closed down; most were taken over by other banks, typically on a weekend so that customers hardly noticed the change in management. A paramount objective was thus not only the preservation of capital but also (and relatedly) continued access to credit. This successful management of problem banks should be compared with the disastrous approach taken in Indonesia, where authorities shut down 16 private banks and implied that still more weak banks might be closed in time. Depositors were put on notice that their deposits were at risk. The resulting run on the remaining private banks was no surprise, particularly because safer alternatives were available: state banks (which many believed had the government's implicit guarantee) and foreign banks (which many believed were sounder). Even if these safe havens had not been available, depositors could have taken their money and put it into bank accounts denominated in foreign currency (thereby at the same time avoiding the downside risk of devaluation). As private banks weakened, the supply of credit was disrupted, contributing to the decline in the economy.

Restructuring financial institutions typically involves stripping out the bad assets into an asset management agency. In the aftermath of the savings and loan debacle in the United States, the acquiring agency was the Resolution Trust Corporation. What value is associated with this rearrangement of the control of assets? There are three possible answers, of varying merits. The first, and perhaps the most important, is that the compensation paid by the government to the bank for these assets exceeds their actuarial value. In effect the asset resolution process is a subtle way of providing a hidden subsidy. The second - and most persuasive, if true-is that by specializing in the management of nonperforming assets, the asset management agency can enhance the value of those assets; it has an absolute advantage in workout techniques. This expertise is more convincing in the case of real estate assets (the bulk of those managed by the Resolution Trust Corporation). In fact, it did a very credible job in disposing of the nonperforming assets, helped by the renewed strength of the real estate market following the drop in interest rates. But there is little confidence that it would have done as well had it been saddled with the responsibility of managing controlling interests in corporations, such as General Motors or Ford. Third, stripping out bad assets allows banks to focus attention on new lending activities and reduces uncertainty about the value of their existing portfolios, which, given the risk of default, might have induced behavior that amounted to looting the banks.

Monetary policy in the midst of a crisis can either exacerbate or mitigate the problems associated with financial institutions. High interest rate policies typically have a variety of adverse effects on financial institutions. They lead to a decline in asset 
values, resulting in more mortgage defaults. More firms face financial constraints, leading to additional nonperforming loans and corporate bankruptcies. The sharp changes in asset values associated with higher or lower interest rates increase uncertainty about the value of different enterprises, exacerbating informational problems within the economy. In countries where banks can invest in equities, lower equity prices (which typically follow from higher interest rates) further erode the banks' net worths. Moreover, the higher interest rates on government bonds often contribute to a scarcity of funds for lending to enterprises; banks find it more attractive to lend to the government. (There are some exceptions: In countries where banks do not perform the standard intermediation functions, but rather largely hold government bonds, higher interest rates may enhance banks' cash flow. Although this improves the financial position of banks, it impairs the overall strength of the economy.)

\section{Concluding Remarks}

Financial crises have become more severe and more frequent in the last quarter of a century, at least in part because of financial- and capital-account liberalization without the appropriate regulatory framework. The issues are broader: the 200-year history of modern capitalism has been marked by repeated macroeconomic disturbances caused by financial weaknesses, and only strong governmental regulation of that sector has brought a modicum of stability.

With respect to regulation, two final observations about financial restructuring are worth noting. First, the costs of restructuring can be divided into two components. One arises from the negative net worth recorded by many banks because of the high level of bad loans. Where protection is provided in the form of deposit insurance, the government is obliged to fill the gap. This represents a redistribution from taxpayers to depositors, a transfer payment that has a fiscal cost. It does not use real resources and, in that sense, is not inflationary. Moreover, although the government may have committed itself to repay depositors, it typically has not made a commitment on the interest rates it must pay. It may, for instance, contemplate restricting loan withdrawals and limiting the interest rate paid on deposits; alternatively, it can allow deposit withdrawals but restrict transfers of capital abroad. These are examples of ways in which the costs of fulfilling the government's commitments may be contained-ways that are less distortionary than the more traditional ways of inflating away the value of monetary claims.

The second component of the cost of restructuring involves the capital required to restart the banking system. Such schemes can be funded in ways that entail low interest costs. For example, the government can borrow from the banks at low interest rates and invest the money in the banking firms. Although such transactions may 
meet capital adequacy standards, they do not resolve incentive issues. They may, however, serve to restore confidence. It is also important to note that in terms of the government's budget, these financial transactions rightly belong in the capital account, not the recurrent account, and therefore should not crowd out other output-, growth-, or equity-enhancing forms of public expenditures. Unfortunately, if costly ways are employed for financing the restructuring of the banks and if the distinction between capital and recurrent budgets is not made, there is a real danger that restructuring expenditures will crowd out other expenditures to the detriment of economic recovery. Thus, it is essential to balance the benefits and costs of alternative ways of spending scarce public funds.

The second observation relates to the phenomenon that as an economy goes into recession and lending is discouraged because of the poor prospects facing the economy, the liquidity of the banking system sometimes increases among banks that do not face massive withdrawals. Some economists, worried about inflation, naively argue for mopping up the liquidity. But governments typically have only blunt instruments for doing so, and hence banks, finding their constraints tightened further, decrease lending yet again, and in so doing exacerbate the downturn. More generally, worries about inflation in the face of massive excess capacity are likely to be misplaced. The relationship among aggregate economic variables (including that between monetary aggregates and output) may be greatly disturbed in an economy in which the financial sector is disrupted. The U.S. Federal Reserve learned this lesson in the early 1990 s at significant expense to the economy.

Even under systemic crisis conditions, international experience indicates that forbearance is dangerous when lax standards are issued in the hope that the situation will subsequently improve. Therefore, when opting for some form of supervisory forbearance, it is important to avoid exacerbating moral hazard problems through more stringent supervision and regulation. Regulators need to address several questions, including which banks or portfolios qualify for supervisory forbearance as safeguards against connected lending or looting and how to increase proactive regulation and supervision.

The problem is that all too often, regulation goes beyond efforts to enhance the safety and soundness of banking systems. There are, for instance, frequent attempts to repress competition that are not justified by the objective of increasing franchise value to enhance prudential behavior. Incumbents in any industry try to protect themselves against the pressures of new entrants. Although a wide array of arguments are brought to bear in support of such contentions, it should be clear that these are typically no more than self-serving arguments of special interest groups attempting to maintain their monopoly rents.

Countries, such as India, that have had a long history of government intervention in many sectors of the economy need to be especially sensitive to these arguments. By and large, competition is the most efficient mechanism for encouraging efficiency 
and innovation. The challenge is to enhance competition, openness, and innovation in the financial sector while maintaining sound prudential oversight, appropriate incentives, and needed constraints. This approach can help ensure that the kinds of crisis that have marred the success of East Asia are not inflicted on the far more vulnerable economies of the rest of the developing world.

\section{Notes}

Joseph E. Stiglitz is a professor of economics at Stanford University.

1. Caprio and Klingebiel (1996) identify banking crises—defined as episodes when the entire banking system has zero or negative net worth-in 69 countries since the late 1970s. They only cover countries with sufficient data and estimate that including all of the transition economies would add at least 20 more countries. With a less stringent definition, Lindgren, Garcia, and Saal (1996) estimate that three-quarters of IMF member countries experienced "significant bank sector problems" at some time between 1980 and 1995. They identify "banking crises" in 36 countries, or one-fifth of IMF member countries.

2. As Caprio (1997) has often pointed out, there are two kinds of economies: those that have deposit insurance and those that have it but do not know it yet.

3. Some analysts have argued that this problem arises because of deposit insurance. Without deposit insurance, those gambling with the bank's funds would be unable to attract depositors. As noted earlier, implicitly, at least, virtually all countries offer deposit insurance, at least to banks that are "too big to fail." But even apart from this, Hellman, Murdock, and Stiglitz (1998) show that the same perverse incentives arise in banking systems without deposit insurance.

4. A complementary approach to international banking standards has been proposed by Goldstein (1996).

5. Borrower incentives are strongly affected by the legal environment and market conventions. In some states in the United States, for instance, real estate loans are nonrecourse, so that the collateral is the only asset that can be attached in the event of nonperformance. In other states, other assets can be seized, although in the event of bankruptcy only the lender has seniority status with respect to the collateral. Incentives of borrowers are markedly different in the two regimes, which reflect different views of creditor and debtor rights-conflicts that appear throughout bankruptcy law.

6. For a theoretical development of this point, see Edlin and Stiglitz (1995). Marking to market does not fully resolve the problem so long as there are some assets that cannot be marked to market. Then stringent enforcement of capital adequacy standards may lead to an investment being distorted into assets where that is not feasible or at least not done. If those assets are, at the same time, riskier (which may or may not be the case), then actual risk taking could increase.

\section{References}

The word "processed" describes informally reproduced works that may not be commonly available through library systems.

Akerlof, George A., and Paul M. Romer. 1993. "Looting: The Economic Underworld of Bankruptcy for Profit.” Brookings Papers on Economic Activity 2:1-73.

Caprio, Gerard. 1997. "Safe and Sound Banking in Developing Countries: We're Not in Kansas Anymore.” Research in Financial Services: Private and Public Policy 9:79-97. 
Caprio, Gerard, and Daniela Klingebiel. 1996. “Bank Insolvencies: Cross-Country Experience.” Policy Research Working Paper 1620. World Bank, Policy Research Department, Washington, D.C.

Caprio, Gerard, and Dimitri Vittas, eds. 1997. Reforming Financial Systems: Historical Implications for Policy. Cambridge: Cambridge University Press.

Edlin, Aaron, and Joseph Stiglitz, 1995. "Discouraging Rivals: Managerial Rent-Seeking and Economic Inefficiencies.” American Economic Review 85:1301-12.

Goldstein, Morris. 1996. "Case for an International Banking Standard.” Policy Analyses in International Economics 47. Institute for International Economics, Washington, D.C. Processed.

Hellman, Thomas, Kevin Murdock, and Joseph E. Stiglitz. 1998. "Liberalization, Moral Hazard in Banking, and Prudential Regulation: Are Capital Requirements Enough?” Stanford Graduate School of Business, Stanford, Calif. Processed.

Lindgren, Carl-Johan, Gillian Garcia, and Matthew Saal. 1996. Banking Soundness and Macroeconomic Policy. Washington, D.C.: International Monetary Fund.

Rodrik, Dani. 1998. "Who Needs Capital-Account Convertibility?” Essays in International Finance (Princeton University) 207(May):55-65.

Ross, S. 1973. "The Economic Theory of Agency: The Principals' Problem.” American Economic Review 63:134-39.

Shleifer, Andrei, and Robert W. Vishny. 1997. "Limits of Arbitrage." Journal of Finance 52(March):3555.

Stiglitz, Joseph E. 1974. "Incentives and Risk Sharing in Sharecropping." Review of Economic Studies 41(April):219-55.

—. 1992. "Banks versus Markets as Mechanisms for Allocating and Coordinating Investment." In J. A. Roumasset and S. Barr, eds., The Economics of Cooperation: East Asian Development and the Case for Pro-Market Intervention. Boulder, Colo.: Westview Press.

—. 1993. "Perspectives on the Role of Government Risk-Bearing within the Financial Sector." In Mark S. Sniderman, ed. Government Risk Bearing. Norwell, Mass.: Kluwer Academic Publishers, pp. 109-30.

$$
226 .
$$

Vives, Xavier. 1991. "Regulatory Reform in European Banking." European Economic Review 35(23):505-15. 
Copyright of World Bank Research Observer is the property of Oxford University Press / UK and its content may not be copied or emailed to multiple sites or posted to a listserv without the copyright holder's express written permission. However, users may print, download, or email articles for individual use. 